\title{
PERSPECTIVE OPEN Pitfalls in transboundary Indus Water Treaty: a perspective to prevent unattended threats to the global security
}

\author{
Muhammad Uzair Qamar (D) ${ }^{1 *}$, Muhammad Azmat $\mathbb{D}^{2}$ and Pierluigi Claps (iD ${ }^{3}$
}

Water treaties have played an important role in peaceful resolution of water-related conflicts. Although the mode of negotiation to resolve water-related conflicts may vary from treaty to treaty, a number of structural falls make them unprepared for the future needs. The Indus water treaty is perhaps quoted as the most successful water-sharing mechanism in the recent times. Against all odds, the treaty has fulfilled its job descriptions of being a mechanism providing a moderately reliable framework for the peaceful resolution of water-related conflicts. However, the climate change is quickly eroding that trust. The water-sharing mechanism lacks guidelines to cater the issues related to climate change and basin sustainability which require integrated approach for their addressal. But the structural inflexibility does not encourage the riparian to collaborate and build mutual trust for common good. The riparian countries, within the framework of treaty, attempt to elevate their national interests by deliberately refusing to comply with the treaty clauses in letter and spirit, and even manipulate data to deprive the competing riparian of water. We propose and argue on the need of adopting structurally sound forum for solving water conflicts which will assist in comprehensive policymaking to ensure the sustainability of transboundary water resources. The forum will also provide an opportunity for the riparian to work together towards confidence-building through sharing of real-time hydrological data and further scientific analysis based on that. Conclusively, the shortcomings of the present conflict-resolution method are addressed by encouraging riparian to collaborate at various levels.

npj Clean Water (2019)2:22

; https://doi.org/10.1038/s41545-019-0046-x

\section{INTRODUCTION}

Globally, almost $60 \%$ of the total freshwater resources are supplied by the transboudary river basins. ${ }^{1}$ However, an estimated $40 \%$ of these basins are governed by some sort of basin agreement, which provides a framework to resolve disputes between the signatories. ${ }^{2}$ These existing transboundary watersharing treaties are vital in guaranteeing global peace. ${ }^{3-6}$

During the days when majority of these water treaties were signed, the term "climate change" was unheard-of. Conversely, climate change is now considered to be the most potent threat to the sustainability of global water resources. In fact, for some regions the river flows are already squeezing under the influence of climate change (e.g., Indus River and Colorado River). ${ }^{7,8}$ Among the affected river basins documented by the Intergovernmental Panel on Climate Change (IPCC) report, Indus river basin is located in the worst climate change affected area. ${ }^{9,10}$ India and Pakistan share the major portion of the Indus basin water resources under a treaty known as Indus Water Treaty (IWT). With the World Bank being the guarantor, the treaty after being signed, survived three wars, expeditious decolonization, and disproportional geographical development. However, the climate change is quickly changing the balance. ${ }^{11}$ The flow data of Indus river between 1962 and 2014 showed a 5\% decrease in the flow magnitudes. ${ }^{12}$ It is further projected that the climate change-related threats can reduce Indus river flows as much as $30-40 \%$ in the future. ${ }^{13}$ The picture gets very disturbing, once this aspect is combined with the fact that the population of the region is on the rise. The increasing population trend will put more pressure on the water resources of the basin, which can have serious adverse impacts on the regional peace. As a tipping point to the obvious consequences, during the past decade a series of water-related conflicts have been raised between the two countries to an extent that, recently, the Indian Prime Minister (PM) while addressing the farmers in Indian Punjab vowed to end the treaty unilaterally. ${ }^{14}$ In a strong rebuttal, Pakistan categorized the unilateral revocation of IWT as an act of war. Although the statement of Indian PM could be considered as a result of mounting public pressure for more water for agriculture which is the main commodity of the region and helps keeping masses above the poverty line, it perhaps stated the obvious fate of the ageing document under the changing climate. The dissolution of IWT, in the presence of severe hostility that exists between India and Pakistan, will seriously hamper the regional peace. Historically, the transboundary water crises of the region were considered localized with no eminent threat to the global security, but the situation now demands more holistic approach in the region possessing nuclear arsenals. Prior to becoming the nuclear powers, both countries fought three wars. The role of global community in these wars was only of intermediaries for truce without having any potent existential threat. However, the growing water demand and lesser supplies now make nuclear war a plausible reality that could cause starvation and hunger on an unprecedented scale. ${ }^{15}$ Considering the global nature of potential nuclear disaster, the world community needs to integrate and function in a unified manner to overcome these increasingly complex challenges of transboundary river basins. ${ }^{16}$

The case study of IWT is a classic example of a ticking timebomb which will eventually explode under increasing demand and lower supplies. However, the treaty defines absolutely no mechanism to encounter the climate change adversities, whereas the global efforts for the addressal of climate change impacts on

\footnotetext{
${ }^{1}$ Department of Irrigation \& Drainage, Faculty of Agricultural Engineering and Technology, University of Agriculture, 38040 Faisalabad, Pakistan. ${ }^{2}$ Institute of Geographical Information Systems (IGIS), School of Civil \& Environmental Engineering (SCEE), National University of Sciences and Technology (NUST), IGIS Building (2nd Floor), 44000 Islamabad, Pakistan. ${ }^{3}$ Department of Environment, Land and Infrastructure Engineering (DIATI), Politecnico di Torino, Turin, Italy. *email: muhammad.uzair@uaf.edu.pk
} 
the transboundary rivers are disproportional and fail to address the localized issues of global importance. ${ }^{17}$ The resolution of such water-related issues is challenging and requires overcoming a host of overlapping socio-economic, environmental, and policy pressures to assess the climate change impacts on the flows and subsequently translate them into the water-sharing mechanism. This comprehensive translation requires collaboration and trust among countries sharing water resources of a river basin. However, the modern-day treaties in general and IWT in particular do not encourage frequent interactions among the riparian due to structural shortcomings.

This paper will thus investigate the structural shortfalls in IWT and suggest necessary modifications to ensure a long-lasting peace and stability in the region. The IWT is quoted as an example when it comes to solving transboundary water conflicts. ${ }^{18}$ This gives us all the more reason to point out the loopholes in the agreement with the intention of them being rid of in the present and future water agreements. On the basis on extensive literature review and in-depth analysis, we will propose our version of structure of the conflict-resolution method which will address the structural issues of IWT by creating a conflict-resolution method through dialog among the riparian countries followed by the involvement of International overseer in case the conflict remains unresolved. We will also argue on the need for persistent efforts, at the global level, to form an International Climate Change Consortium (ICCC) for Transboundary River Systems supervised by any international organizations affiliated with the United Nations (UN) that could evaluate the impact of climate change on water resources in quantitative terms and act as a legal advisory body to address the emerging issues related to climate change in the water-sharing treaties around the globe. Conclusively, by arguing on a localized problem the obvious aim of our paper is to propose such a practical framework which can be used as a reference at the global level. The impact of study will not be regional but rather global. It might prove as a founding block in executing an agreement similar to that of the Paris Agreement.

\section{MODERN DAY WATER TREATIES: CHALLENGES, OPPORTUNITIES, AND PROPOSED HIERARCHY}

The collaboration and trust among countries sharing water resources of a river basin is mandatory for the peaceful resolution of water conflicts. However, the modern-day treaties do not encourage frequent interactions among the riparian due to structural shortcomings (refer to Fig. 1).

The conflict-resolution method defined in the flow chart is followed by all the major treaties around the globe including (a) IWT between Pakistan and India on the Indus river; (b) Boundary Waters Treaty between Canada and U.S. on Columbia river; (c) the Jordan-Israel Peace Treaty on Yarmouk and Jordan rivers; and (d) Nile Agreement between Sudan and Egypt for utilization of the Nile waters. The treaties (a) and (b) are respectively mediated and arbitrated by the World Bank and International Joint Commissioner (IJC) which automatically mediate when there is a deadlock between the riparian. The US-Canada IJC is a permanent body (or River Basin Organization) established by the treaty, composed of representatives from the treaty member riparian states: the US and Canada. From a structural standpoint, one may argue that IJC is comparable to the Indus Permanent Water Commission (PWC). However, it is evident that the role of IJC in solving water conflicts is far more potent than PWC predominately due to its functional neutrality. ${ }^{19}$ The political establishments of both countries enjoy a great deal of trust on each other. This perhaps is the main reason why it is easier to acquire institutional neutrality in the region even when the experts of both countries are the sole constituents of the forum. On the contrary, in the presence of severe hostility between Pakistan and India, PWC has practically become ineffective and water disputes are always referred to the

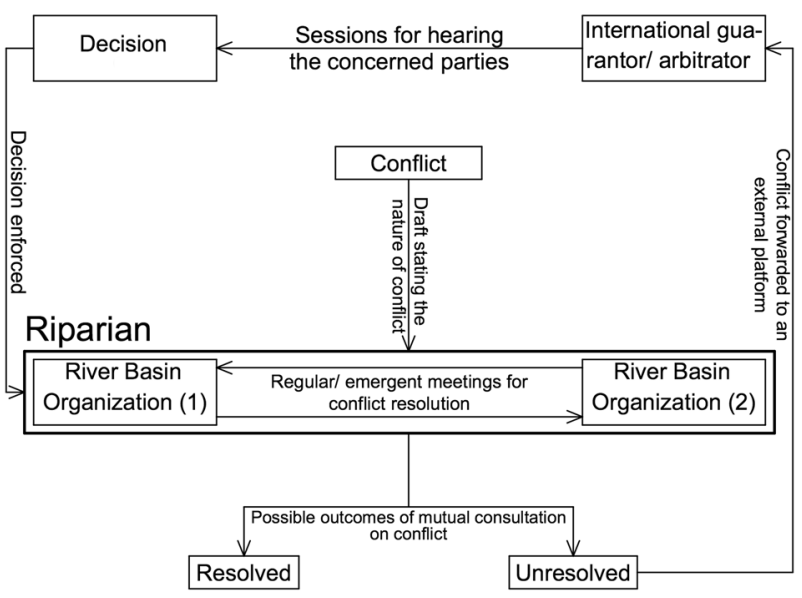

Fig. 1 General conflict-resolution method in international water treaties (bi-riparian model) ${ }^{25-28}$

international guarantor. ${ }^{20,21}$ Therefore, in operational sense PWC is no match to the IJC.

Whereas, the Israel-Jordan water treaty forms a Joint Water Committee (JWC) to resolve water-related matter mutually. Each riparian contributes three members to the committee. The treaty does not involve any third-party guarantor; however, to settle a dispute which remains unresolved even after an extensive discussion at JWC forum, the riparian are directed to seek the assistance of a neutral arbitrator under article 29 of the treaty. ${ }^{22}$ Similarly, the 1959 Nile Treaty establishes a Permanent Joint Technical Committee (PJTC). The PJTC is composed of representatives of Egypt and Sudan. However, in case both parties are unable to address a specific water conflict, an independent body shall be involved to arbitrate between the riparian for dispute resolution. ${ }^{23}$ The effectiveness of a guarantor or arbitrator is entirely dependent on its impartiality and impeccable trust shown by each riparian on its role as a mediatory. The level of mutual trust between the riparian decides whether the conflicts are resolved mutually or at a neutral venue. Therefore, even when the committee is exclusively constituted by the members of riparian countries, it can play a significant role in conflict resolution as in case of US-Canada Boundary water treaty. However, in the event of prevailing hostility between the riparian, the mediation role is sought from an independent source.

The water-sharing mechanisms are supposed to follow a predefined set of comprehensive and actionable instructions to resolve a water conflict in a transparent manner. In essence, the maximal transparency in the established modulus operandi is achieved by managing the treaties through a "river basin organization" which is a permanent indigenous body constituted by the representatives from all the riparian. ${ }^{24}$ Apart from ensuring daily flow data sharing between the riparian, the major responsibilities of the permanent body can include: ${ }^{25-30}(1)$ ensure smooth functioning of the treaty on the agreed points; (2) promote cooperative environment between the signatories; (3) maintaining ecological integrity of the shared basin's ecosystem by managing its water resources in a consistent manner; (4) peaceful resolution of water-related conflicts; (5) sustainable management of transboundary water resources to fulfill the present and future needs of dependents; (6) authorizing each riparian to manage or use the available water resources within its legal domain as long as such management does not disturb the ecological integrity of water resources within the jurisdiction of other riparian; and (7) establishing a regional mechanism to improve the flood forecasting and management system.

Apparently, the job descriptions of a permanent commission are quite comprehensive. However, it has failed to deliver in 
prompt resolution of water-related conflicts. ${ }^{20,21}$ There are various reasons for this failure in the conflict resolution. In the following subsections, the four major ones are described and commented. The suggestions later proposed in this paper directly follow from this analysis. The primary reasons for this failure are as follows.

Absence of supervision of international guarantor to enforce sharing mechanism

The modern-day water treaties and agreements can be broadly classified into three main categories, each defining a separate conflict-resolution method. The categories include (1) competing countries' governments resolving the conflict through dialog or mutual understanding; (2) resolution through a third-party guarantor; and (3) no conflict-resolution method. According to the Transboundary Freshwater Dispute Database (TFDD), developed and maintained by the Oregon State University, 145 waterrelated treaties were negotiated for transboundary rivers in the 20th century to govern hydropower generation and water supply. Surprisingly, $80 \%$ of the signed water treaties lack any enforcement mechanism. ${ }^{11}$ Additionally, a number of treaties include only a primitive monitoring mechanism with no conflict-resolution method. ${ }^{31,32}$

The IWT falls into the second category. The World Bank is the guarantor of IWT; however, its role is only of a conflict solver. The guarantor relies on the riparian to report any issue related of illegal intervention in the river flows. However, there is no definite way of knowing if illegal intervention really happened or it is only a case of low seasonal flows due to climate variability.

Lack of collaboration and mutual trust

The long-lasting cooperation to manage transboundary water resources can be achieved by establishing joint institutions. However, with only a limited number of transboundary rivers governed by treaties and even smaller number of them being multilateral in nature, the possibility of having a global forum to address water-related conflicts across the globe is very oblique. ${ }^{33}$ Moreover, the authority, scope, and roles of these established frameworks vary widely. Even in the more established treaties like IWT, the structure does not encourage interactions between riparian which is essential for trust building. This is the main reason why besides being operational for almost six decades, questions are still being raised on its sustainability.

The ideal framework would encompass the riparian countries, and a neutral legislative authority that would enforce the approved law in the water-sharing mechanism. However, such a forum may be deemed as a threat by the more powerful countries for fear of losing political influence. ${ }^{34}$

No regular data sharing as planned in the treaty

The flow data sharing is significantly important to understand the dynamics of river basin in totality. Consequently, in all modern water treaties, the riparian are directed to share the flow data. However, international water treaties do not define any method to validate the quality of the shared data. Historically, data sharing for supporting applied research is an exception rather than a policy. Even in the agreed and functional water treaties (e.g., IWT), the flow data sharing which is an integral part of the sharing mechanism is frequently unfulfilled.

Non-involvement of interactive research community

Additionally, even when the data are shared there is no mechanism for the research community to get an access to it. ${ }^{17}$ This issue can be resolved by promoting open data policy to give free data access to international supervisory bodies and other stakeholders for promoting transparency and applied scientific research. ${ }^{31,35,36}$ Some experts believe that sharing of trusted flow data can exponentially ease the tension among the riparian and diverts leaders to evenly focus on the crisis. ${ }^{37}$

\section{POSSIBLE AGREEMENT MEASURES TO FACILITATE TREATIES REVISIONS}

The basis of all the aforementioned barriers are linked to the lack of institutions which could mutually collaborate to overcome the regional challenges and build confidence of riparian countries on each other. Our proposed structure of the TF will address these issues by creating a conflict-resolution method through dialog among the riparian countries followed by the involvement of International overseer in case the conflict remains unresolved. However, the proposed joint action plan requires some prerequisites to be completed for its strategic implementation. To start with, the stakeholders need to form an internal mechanism for the real-time monitoring of flows along the length of the transboundary rivers. The other prerequisites include (1) real-time sharing of flow data with the concerned parties; (2) a research wing to identify the effects of changing climate on the river flows; (3) a governing body to supervise the research wing and data collection mechanism; (4) a combined forum containing officials of all the riparian countries to make a decision on the conflict; and (5) an international guarantor to supervise the treaty.

Putting all prerequisites together, a new type of "transboundary forum" (TF) is elaborated, which follows the schematic diagram presented in Fig. 2.

The implementation of the TF, specifically within the context of IWT, does not require any sophisticated innovation strategy. The operational frameworks of IWT was finalized through negotiation between the World Bank and the riparian. The same procedure will have to be adopted to set-up the proposed forum. The proposed forum will inherit its financial structure from already operational treaty. The respective riparian will be responsible for the financial support of data collection mechanism, research wing, governing body, and representatives of combined forum. In addition to these establishment costs, the periodic mediation of international guarantor does require the fee of mediator, the costs of venue, and the anonymous reviewers' fees to be borne by the riparian (for details, the readers are referred to ref. ${ }^{38}$ ).

The proposed structure of TF can work for all transboundary treaties having a third-party guarantor or a clearly defined mechanism to hire an international arbitrator to enforce a

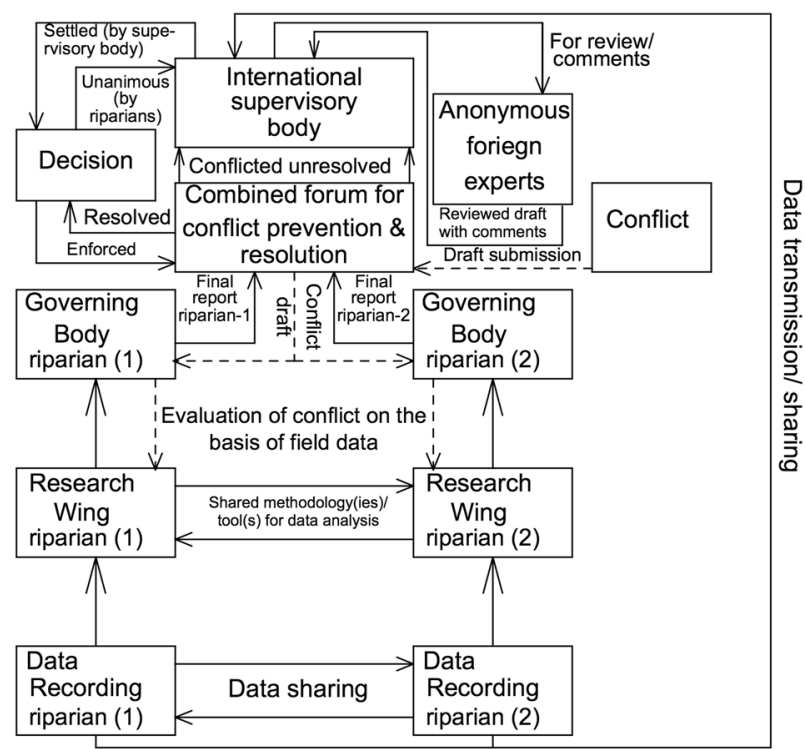

Fig. 2 Proposed conflict-resolution method for international water treaties 
decision. Undoubtedly, there are very few operational treaties which possess a third-party guarantor. ${ }^{39}$ However, after the adoption of UN Watercourse Convention, 1997, the riparian have been given the right to seek the assistance of a mutual arbitrator under Article 22 of the convention, to avoid any deadlock. ${ }^{40}$ The hired arbitrator resolves a water conflict by rendering a binding decision. Therefore, basins that do not have a third-party guarantor can also move towards adopting a TF provided the treaty outlines a framework for the hiring of an arbitrator.

Apart from ensuring that dead-end scenarios are avoided, these "guarantors" or "arbitrator" will further "guarantee" conflict resolution, either internally through river basin organizations of respective riparian or externally by a guarantor (or a hired arbitrator), as opposed to simply representing the forum in which conflict-resolution efforts may take place. However, the effectiveness of any guarantor is entirely dependent on its impartiality and impeccable trust shown by each riparian on its role as a mediatory. The level of mutual trust between the riparian decides whether the conflicts are resolved mutually or at a neutral venue. Therefore, even when the committee is exclusively constituted by the members of riparian countries, it can play a significant role in conflict resolution as in case of US-Canada Boundary water treaty. However, in the event of prevailing hostility between the riparian, the role of a guarantor is sought from an independent source.

\section{HOW THE TF IS SUPPOSED TO WORK}

In the following lines, the operative connections between the elements of the suggested system and the building of the consensus knowledge are addressed. These include the collection and treatment of data which form the basis of water-sharing mechanism under the changing climate.

Clearly, from the SOPs stated in Fig. 2, first step is the sharing of hydrologic data with all the stakeholders and the supervisory body. The poised data sharing is proposed as a mandatory part of the new framework based on the experience learned from the treaties, such as IWT itself, having simple and straightforward standard operating procedures. The IWT is simpler in the sense that it physically divides basin's tributaries between the riparian. According to treaty, three eastern rivers (Sutlej, Beas, and Ravi) were given to India, whereas Pakistan was given control of three western rivers (Indus, Chenab, and Jhelum). An additional clause of the treaty enabled India to construct runoff the river hydropower projects, on the rivers allocated to Pakistan, without disturbing the natural flows. Even with these clear directions, the upstream riparian is frequently blamed for stealing water. The example of Baglihar is there for the taking. This runoff river hydropower project is constructed on the Chenab River by the Indian government. Ever since the commissioning of this project, the Pakistani side, particularly the farmers who heavily rely on Chenab's water to earn their livelihoods consider India responsible for the diminishing river flows. ${ }^{41,42}$ The Indian government held climate change responsible for low flows of Chenab; however, the blame game never stopped. Conversely, with climate change, this mutual distrust is expected to increase. Conclusively, the solutions of transboundary crises are never going to be simple as long as rivers flow across the political borders and there is no live flow data measurement and sharing mechanism.

Based on the acquired data, the joint research wing will periodically assess the anomalies in the flow magnitudes due to the changing climate using predefined set of tools and methodologies. In the absence of a universally accepted method of data analysis, a good choice can be to use different data mining techniques and validate them with actual data, periodically. Over time, the availability of more data will enable algorithms to better analyze the flow data by analyzing the variability and uncertainty of estimates through cross validation techniques. The governing body of technocrats will translate for the policy-makers, the findings of the scientific committee regarding flow anomalies in diminishing (or increasing) forecasted magnitude of flow values. This necessarily needs to happen in the joint forum, as such a forum can induce variations in the functional water-sharing mechanism that are politically acceptable. Considering the nature and functional norms of the document, the joint action committee constituted by the policy-makers is required to make a unanimous decision. In case of conflicting outcome, the assistance of international guarantor will be sought. The guarantor may seek comments from the impartial experts on the issue at hand. The comments are then analyzed in order to reach the final decision which is eventually communicated to the joint forum. The riparian states reserve the right to file a decision review application, if deemed necessary. However, the base of such an application needs to be strong.

While arguing our case for establishing the TF, we place greater emphasis on the role of such a body in building trust between riparian by institutionalizing regular and repeated contacts and exchanges. The long-term solution of the transboundary water conflicts ultimately goes through mutual trust and collaboration. ${ }^{43}$ Keeping in view the accelerated ecological deterioration of river basins, the climate change related threats can never be effectively countered until riparian collaborate on an unprecedented scale. ${ }^{30}$ Without collaboration it will merely remain a dream to address a natural issue which is unknown to any boundary line: in a world distinctly divided on the basis of political ideologies. Such regional coalitions are all the more important because: (1) data alone may not eliminate all risks, ambiguities, and uncertainties and (2) with model predictions on climate change impacts on many basins being unclear and pointing in different directions, data analyses by a potential TF may not soon standardize these impact projections on temporal and geographical scales useful to policymakers. In comparison with the previous conflictresolution structure in IWT, the proposed forum offers broad spectrum of engagement for confidence measures at the various levels. Measures such as routine data sharing and making academics and researchers part of the process not only strengthen the knowledge base but also improve the interaction between the parties upon which trust and cooperation can be built. The roles of TF which are appropriate and applicable to set-up direct contacts between the parties are:

(1) Ensuring all riparian maintain desired level of cooperation among them. In case any riparian deviates from the rules, the TF has a mandate to send notice to noncooperation member.

(2) Settling the complaints about the quality of data or analysis received from the other riparian by getting it reviewed from the foreign anonymous reviewers. Additionally, if the satisfaction of any complainant requires visiting the sites located in the area controlled by the other riparian, the TF will ensure the visits of complainant to confirm the authenticity of the claim made by the defendant. In the long run, when confidence will eventually develop between the riparian, the scope of these visits may also encompass the investigation of anthropogenic activities potentially resulting in the deterioration of ecological health of the river basin and need not to be limited to the inspection of hydraulic structures as in traditional treaty.

(3) Assisting riparian in adopting similar climatic factors including the ones driven from anthropogenic activities for the analysis of climate change impacts on river flows and seeking comment from anonymous experts in case of a deadlock. In the context of scientific research, having common parameters is very important as a number of socio-economic and topographic attributes strongly influence the river flows. ${ }^{44}$ The selection of the most relevant 
parameters or induction of new parameters in future for the analysis of their impacts upon river flows could require the role of third-party and anonymous reviewers in the face of contradicting arguments. The idea of having selective parameters is to have concentrative efforts to study the impact of most relevant and scientifically understood parameters on the river flows with an intention to minimize or ideally halt the negative changes in flows through the management of basin ecosystem. Through shared data, the riparian can identify the factors which influence the flow magnitudes adversely and work together for the rectification.

Additionally, the treaties which lack enforcement mechanism are influenced by the regional powers. The case of Nile Agreement is there for the taking. Egypt, as a regional power, had a complete dominance over the control of Nile waters. ${ }^{45} \mathrm{~A}$ series of prolonged internal conflicts and consequent economic frailty in Ethiopia barred the country from challenging the Egyptian status quo in the region. ${ }^{46}$ In the absence of any neutral administrator, the Ethiopian establishment could not find any relief within the framework of treaty. However, post 1991, when Ethiopia showed exponential economic advancements, it was able to resist Egyptian hegemony on Nile waters through the unilateral infrastructure development on the upstream side. ${ }^{46}$ Currently, Ethiopia is constructing the Grand Ethiopian Renaissance Dam (GERD) on the upstream of the Nile river, whereas despite its diplomatic and saber-rattling efforts, Egypt has failed to convince Ethiopia to halt the project. On the contrary, Egypt fears that the filling of the GERD reservoir would give Ethiopia an exclusive right to use Nile waters. The 1959 treaty did accord the largest share of the Nile flow to Egypt. The fact that the treaty has no enforcement mechanism enables Ethiopia to alter its actions at will, which is a significant shortcoming of the Nile river treaty. Having no enforcement mechanism once paved the way for an absolute Egyptian domination on the Nile. The same shortfall in the treaty is now being exploited by the Ethiopian establishment to control the Nile waters. To neutralize the potential domination of any riparian, the proposed forum is to be supervised by an International guarantor or a hired arbitrator backed-up by a panel of neutral experts. The supervisory body will further ensure that all riparian cooperate on the matters of mutual concern. In the traditional conflict-resolution method, the third party only mediates when a matter of regional importance prompts into the limelight, whereas the proposed forum, instead of tackling a complex issue evolved from the structural shortfalls of IWT, will rectify the root cause of problems through structural reformations in order to potentially solve the conflicts at the grass root level. The IWT was signed against the backdrop of increased tensions between Pakistan and India on the use of river waters. Ever since its formulation, the treaty offered a framework to resolve water disputes between the signatories. Thus, the role of IWT is potentially limited to a conflictresolution mechanism instead of strengthening the means of contact and interaction between the parties upon which trust, and cooperation can be built. Perhaps that is why the treaty has never been able to establish mutual trust between the riparian. The distinctive structure of the TF makes it a self-propelled platform where roles are comprehensively defined for each stakeholder. The third party is expected to play a managerial role in guaranteeing a platform for these connections. The major responsibilities of the international guarantor include (1) collecting data from all riparian; (2) archiving annual joint communiqués issued by the riparian; and (3) appointing anonymous reviewers in case of an unresolved conflict.

In the hindsight, apart from defining a resolute water-sharing mechanism, the structure of conflict solving forum proposed in present work will also assist in a variety of ways to overcome the other challenges posed by the climate change. The data sharing and research wing will remain functional in collecting and analyzing flow data to prepare an annual comprehensive report on the assessment of the river basin's hydrological responses under the changing climate. The catalog of these reports will be helpful in climate change studies at basin scale and drafting mitigating strategies to ensure the sustainability of basin ecosystem. The real-time data recording mechanism to acquire the information about the impacts of climate change on water resources in numeric terms will also analyze the proportionate role of anthropogenic climate change, land use change, and human activities in diminishing flow magnitudes. The global community has made sincere efforts to minimize the climate change induced by human activities. However, the results of these efforts are few and far between primarily due to non-translation of global policies at regional scale. ${ }^{47}$ The forum provides a methodology for that translation by allowing riparian to observe each other activities which could potentially deteriorate ecosystem of river basin and negotiate with each other for basin sustainability. All in all, the structure of forum is well-thought-out and is required more than ever to avoid any potential conflicts which might adversely affect the global security.

\section{CURRENT CHALLENGES AROUND THE COMPLIANCE OF IWT AND PROPOSED SOLUTIONS}

The looming climate change crisis are exposing the shortfalls of IWT. The continued trend is expected to make the matter worst for the existence of IWT in the long run. We are in fact addressing the core issue which is barring IWT from becoming an effective conflict-resolution forum under the changing climate. To bring such a paradigm shift, the forum, first of all, needs a proper data sharing mechanism on which dialog between riparian could be based. Although IWT directs both countries to share the flow data, however, both parties seldom share it. Moreover, the quality of shared data is also questionable. To address the former issue, we suggest that riparian, instead of only sharing data mutually, should also share it with the International guarantor. However, to enhance the quality of the shared flow data, we recommend complementing it with other hydrological and water-related information as practiced by the Mekong River Commission (MRC) under "Procedures for Data and Information Exchange and Sharing" (PDIES). ${ }^{48}$ By doing so, we intend to replace politically motivated biased reasonings on PWCs platform with well-poised arguments based on the quality data. The scientific community will execute their conclusions from the analyses based on reliable data. With the usage of reliable data and established methodologies for data examination, the room for political biasness will be very small. Thus, the possibility of reaching a mutual agreement without involving the third-party are bright.

Besides structural and procedural deficiencies, the general public and stakeholders in the developing countries are rarely aware of the climate change threats making it practically impossible to effectively emphasis on the need of joint basin management under the changing climate. ${ }^{49}$ The present debate on the impacts of climate change on water resources has generalized the issue to an extent that the general public is oblivious to the intensive anthropogenic activities that result in such a change. Essentially, the growth in population and ungoverned urbanization in the transboundary basins like Indus also affect the river flows by altering the river morphology. These factors are seldom discussed but can have far-reaching effects towards the peaceful resolution of the future water-related conflicts. The Indus basin is presently accommodating 300 million people. $^{50}$ The basin, thus, has one of the highest population densities in the region owing to the social taboos and underdeveloped economy. ${ }^{51}$ A significant $61 \%$ chunk of the population is living in Pakistan, while $35 \%$ resides in India. ${ }^{52}$ The population is projected to reach 383 million by $20500^{53,54}$ Apart from increased 
water demand, the population growth is also deteriorating the basin ecosystem and ultimately reducing the natural water supply. ${ }^{55}$ In the face of diminishing water supplies, the Indus basin is expected to feed 26 million lesser people (than it does today) by $2050 .^{56}$ The influence of this humongous population growth on the water demand urgently requires the participation of the community to implement measures through which the sustainability of river basin management can be guaranteed. To boost community involvement, a qualifying aspect of the proposed process is the involvement of research communities in the data analysis and in the building of scientific reports that can be clearly understood by both the decision makers and the general public. This will not only ensure transparency in the watersharing mechanism but also help understanding the river flows under the changing climate. The interpretation and understanding of climate change impacts on water resources at the level of general public and policy makers will help in resolving the paradoxes of public participation in basin management.

Though under traditional constitution of IWT, the riparian may create joint commissions or other entities to involve policy makers. However, the provision did relatively little to foster frequent and strong engagements between the concerned parties. The Article IX clearly directs the riparian to interact at two levels: (1) PWCs and (2) governments. Theoretically, the PWCs are constituted as a regular body: dedicated to meet on regular basis (at least once a year) to ensure IWT's implementation in true letter and spirit. In case any conflict arose between the riparian and any of the two governments conclude that the PWCs would delay the processing of any dispute, it could directly invite its counterpart for a speedy agreement. The invitation of direct agreement is subjected to the approval of all the concerned riparian. However, the forum of PWCs is largely dominated by senseless political motives. Perhaps that is why the riparian have never been able to solve any major conflict at the level of PWCs and had to sought third-party mediation for the resolution. ${ }^{57}$ Even the disputes like Kishanganga and Baglihar had to be mediated by the World Bank. Thus, frequently seeking the mediation services of International Court of Arbitration on every issue seriously jolts the mutual trust. A complete failure to resolve any major dispute at the level of PWCs explains the inability of both riparian to address the local disputes primarily due to dominant political interests which are served at the cost of mutual trust. The proposed forum will gradually encourage the riparian to resolve their disputes locally by working bilaterally towards the sustainability of the river basin which is presently not in the discussion even at the highest level.

Another paramount concern of the IWT is the role of China and Afghanistan which has always been considered insignificant. However, in the wake of recent political developments in the region, their role can no longer be ignored. The South Asian politics plays a very provocative role in transboundary water issues. The present political demarcation is drawn between Pakistan-China and India-Afghanistan. Much of the regional politics is defined by the intersecting interests of four countries (India, China, Pakistan, and Afghanistan) under the influence of which countries align to achieve their national interests by making use of their own or ally's geographical location to intimidate the rival riparian. Unfortunately, the countries have recently started using water as a pressure tactic against the rivals. The verbal clashes between riparian amid the announcements of construction of dam on Kabul river and Lalho hydropower project on Brahmaputra river offer a tangible explanation on how IWT signatories are using their friendly relationship with other regional countries as a tool of coercive diplomacy against each other. The decision of Afghan government to construct a dam on the Kabul river through financial support of India did not go down well with Pakistan. The increasing Indian involvement in Afghanistan is seen by Pakistan as a threat to its national security. The Kabul is an important tributary of Indus which contributes 20-28 MAF to the river flows. The supplied water is indispensable for fulfilling water demands of Khyber-Pakhtunkhwa province of Pakistan. Similarly, the water-related tensions between India and China have also prevailed recently. In 2016, China making use of its geographical location blocked a tributary of Brahmaputra river in the Tibet region. ${ }^{58}$ Even after consistent Chinese assurances that the project will not interrupt natural flows to India, many saw it as a warning to Indian government to refrain from bullying Pakistan by strangulating its river flows. Consequently, the non-inclusion of China and Afghanistan enables Pakistan and India to use friendly alliance with these countries to pressurize each other which otherwise becomes impossible due to the restrictions inflicted by IWT. Present South Asian water diplomacy needs to concurrently confront these challenges by including China and Afghanistan as a part of water-sharing mechanism. The structural flexibility of TF allows easy induction of a new riparian. In the presence of clear guideline, the evolution of institutions prerequisite to conduct the day-to-day affairs imperative to TF will be a straightforward process.

\section{DISCUSSION}

The issues of transboundary river treaties within the paradigm of climate change have been discussed in the literature. ${ }^{59}$ However, resolving these issues through a TF has never been the part of any discussion despite the fact that the climate change related research yielded ground breaking conclusions in the recent decades. The scientists identified regions around the globe which are potentially going to be worst affected by the climate change. All this became possible, exclusively, because of extensive availability of high-resolution data on climatic parameters (e.g., temperature and precipitation) on global scale with the help of remote-sensing satellites which took international borders out of equation. $^{60}$ The policy recommendations proposed in the published literature played an important role in drafting the Paris agreement. ${ }^{61}$ However, on the impact of changing climate on the magnitude of river flows, no standard global conclusions are available owing to the complex-dynamic response of the river flows to the climatic and geomorphologic characteristics of the basin. This sometimes leads to the opposing scientific findings for the same river basins. ${ }^{62-64}$ Inarguably, much of such uncertainties in the case of transboundary river basins, such as Indus, come also from the complex hydrological nature of the basin, involving a number of countries sharing the basin's water resources for overlapping interests. These uncertainties can be significantly reduced by sharing high-resolution data, periodically, to cross validate and improve the modeled findings on the river flows.

Indeed, the rivers have been crucial for the agricultural-driven South Asian economies. Alongside agriculture, they play a pivotal role in energy generation, industries, and environment preservation. The increasing population and lesser water supplies under the changing climate are considered to be the major barriers in exploiting the developmental opportunities related to the river waters. Coordinated regional policies for the river basin management and mechanisms to monitor and share the real-time river flows can even help overcoming political instabilities and mitigating the threats to these opportunities.

The transboundary river basin management cannot be guaranteed by executing decisions in isolation, due to complex nature of the problem. ${ }^{65}$ The decisions based on local considerations can lead to misleading conclusions, potentially affecting the regional peace and stability. A more integrated approach towards the solution of transboundary issues not only contributes to the substantial regional development but also promotes regional peace by providing riparian countries with an opportunity to work towards the common goals with mutual understanding.

In this direction, the proposed hierarchical TF will address the aforementioned issues by ensuring legal support to this 
understanding. For instance, the signatories should be legally bound to share the flow data with the international supervisory body which will have the authority to share it with the other riparian. The shared data will subsequently be analyzed for varying flow magnitudes under the changing climate by the research divisions of the riparian countries by using mutually agreed and universally accepted methods. The data sharing will not only assist in developing a precise global picture of climate change impacts on the water resources of a transboundary river basin but also enhance the productivity of scientific research. The latter can play a deciding role in mobilizing the society which eventually will have to act responsibly to avert the impending catastrophe. Although overwhelming majority of climate scientists agree on the fact that human activities are mainly responsible for climate change, significant portion of general public as well as legislators even in the most developed countries do not agree with this narrative. ${ }^{66}$ Unless the general public is educated and involved in the management of river basins, the era of denial of scientific truth will not be over. The involvement of the scientific community will lead to publishing of findings, resulting in public awareness. Perhaps, this aspect is least served by the present conflictresolution method where bureaucracies involved in the dialog tend to serve their own political interests. With science involved in the decision-making, the sustainability of the river basin will become prime objective outclassing illogical and ambitious political rhetoric.

The proposed forum is initially proposed for IWT for two main reasons:

i. The interest of global community will be greater in the case of IWT as two nuclear powers are involved. To our knowledge no other water treaty involves two rival nuclear power nations. It will be easier to unite international community on this issue concerning global security.

ii. The prerequisites required for the proposed forum are already "concealed" in IWT including data sharing and enforcement mechanism. Therefore, we expect that the least amount of effort is required to transform IWT into a proper TF as compared to any other major functional water treaties.

Obviously, based on the past experience of major water conflicts in the region, one is right in concluding that the conflicts are more likely to revolve around the perceived impacts of infrastructure development on the flows of the Indus river. However, the case of Baglihar on Chenab river offers a different insight into the conflict-resolution mechanism. The hydropower project earned its legality through third-party mediation after Pakistan lodged a formal complaint against it, stating it to be a violation of treaty. However, during low flow season, the upstream riparian was consistently blamed for altering the natural flows of the Chenab river. The most daunting interpretation this project offers about IWT, besides offering a detail mechanism to address the complaints of respective riparian related to the development of hydraulic infrastructure, is its illpreparedness to take up the climate change challenges. Moreover, the regional trend of increasing population resulting in more demand for electricity is expected to exponentialize the construction of hydropower projects on the upstream reaches of the Indus. In fact, according to an article published in Reuters the Indian government is already planning to construct more hydropower project on Pakistani rivers. ${ }^{67}$ The construction is expected to fuel the tensions between the riparian. Therefore, the mutual trust is the key to quantify the impacts of climate change on water resources and seize the trans-regional threats. To overcome the mutual distrust, the forum offers interaction between riparian, at three different levels, to examine a conflict based on the analyses of the experts from the both sides concluded from transparent and comprehensive data. However, the addressal of population-related issues require actions which will involve revisiting the socio-cultural modalities through basic education at the grass root level. Such discussions go beyond the scope of our paper. However, we expect that under increasing pressure of growing population on water resources, the region will eventually broaden the scope of treaty in the long run.

\section{CONCLUSION}

The transboundary water issues are always complex in nature due to the involvement of multiple countries with a wide range of political, economic, and social concerns related to water. However, to tackle the threats posed by climate change to the sustainability of river basins, there needs to be a cross border realization, commitment, and action. Achieving this shared vision among the riparian countries can be facilitated by creating joint institutions to focus on priority issues of mutual interests. The joint institutions will initially break down the complicated issues into more manageable priorities. Afterwards, there is a need of strong political will at the highest level to ensure; first of all, the formation of such institutions and then their smooth operation for the implementation of agreed policies. The formation and operation of such institutions could be slow and ineffective in the absence of political commitment.

Evidences from proposed approaches for the management of basin ecosystem suggest that the basins need to be considered in totality. Such an arrangement could only be possible in the presence of a workable forum such as the one proposed in the present study. India and Pakistan already have a conflictresolution system in place. Both the countries communicate with each other on water-related issues through so-called PWCs. The system directs the PWCs of riparian countries to have meeting on annual basis. However, the scope of PWCs is very limited. Additionally, the present structure of IWT only treats the symptoms while the root cause remains unaddressed. It only compels riparian to seek third-party intervention for the resolution of their disputes. The riparian countries communicate with each other on a limited scale, and that too is often dominated by the political or national interests. The lack of intent and proper mechanism to mutually resolve water-related conflicts creates an environment of distrust in the region. In the proposed structure, the communication between the riparian countries is encouraged at the various levels. The present flawed data sharing method is suggested to be improved by adopting a two-prong sharing strategy involving riparian and international supervisor. The data sharing will lead to the comprehensive diagnostic analysis of the water resources of the region resulting in joint strategic regional policies needed to achieve the set priorities. Moreover, since the entire technicalities involved in decision-making process are based on actual data, it will therefore form the basis of mutual collaboration towards the basin management and addressal of issues that form the basis of distrust between the riparian. The freshwater resources of the region are also under threat and a regional approach is needed to restore and protect these transboundary ecosystems. ${ }^{68,69}$

With increasing number of water conflicts in the twenty-first century, the ultimate solution for ensuring timely resolution of water conflicts is by recognizing the issue at the global level and form an ICCC under UN as one of its multilateral organizationconstituted by the UN member countries sharing transboundary river basins. The member states will be legally obliged to provide financial contribution to UNICCC in "assessed manner" in accordance with the Article 17 of the UN Charter. ${ }^{70}$

It is our understanding that eventually the air and water will have to be governed through an international agreement because the sustainability of these earth's ecosystem components cannot be ensured through even the most disciplined scientific approach having a localized scale. Therefore, such an approach has to have 
a global understanding with a local perspective. As a matter of fact, significant global steps have already been taken to control the emission rates to improve the air quality. ${ }^{71}$ Similar emergent efforts are required to ensure the water basin sustainability, hence ensuring the sufficient water supplies and quality for domestic and industrial utilization.

Received: 19 December 2018; Accepted: 17 September 2019; Published online: 05 November 2019

\section{REFERENCES}

1. Rivera, A. Transboundary aquifers along the Canada-USA border: science, policy and social issues. J. Hydrol. Reg. Stud. 4, 623-643 (2015).

2. UNESCO. Sharing Water, Sharing Benefits: Working Towards Effective Transboundary Water Resources Management. A Graduate/Professional Skills-Building Workbook (ed. Wolf, A.T.) 284 (UNESCO, Oregon State University, 2010).

3. Wolf, A., Yoffe, S. \& Giordano, M. International waters: identifying basins at risk. Water Policy 5, 31-62 (2003).

4. Yoffe, S., Wolf, A. T. \& Giordano, M. Conflict and cooperation over international freshwater resources: indicators of basins at risk. J. Am. Water Resour. Assoc. 39, 1109-1126 (2003).

5. Barnaby, W. Do nations go to war over water? Nature 458, 282-283 (2009).

6. Brochmann, M. Signing river treaties-does it improve river cooperation. Int. Interact. 38, 141 (2012).

7. Dai, A. G., Qian, T. T., Trenberth, K. E. \& Milliman, J. D. Changes in continental freshwater discharge from 1948 to 2004. J. Clim. 22, 2773-2792 (2009).

8. Cosens, B. The Columbia River Treaty: an opportunity for modernization of basin governance. Colorado Nat. Res. Energy Environ. Law Rev. 27, 1-19 (2016).

9. IPCC (Intergovernmental Panel on Climate Change). IPCC Fourth Assessment Report: Climate Change 2007. Synthesis report summary for policy makers (IPCC, Geneva, 2007).

10. De Stefano, L., Duncan, J., Dinar, S., Stahl, K., Strzepek, K. \& Wolf, A. T. Mapping the Resilience of International River Basins to Future Climate Change-Induced Water Variability. Water Sector Board Discussion Paper No. 15, The World Bank, Washington, DC (2010).

11. Brochmann, M. \& Hensel, P. R. Peaceful management of international river claims. Int. Negotiation 14, 393-418 (2009).

12. Qiu, J. Indus river waters shrinking. Nature 534, 600-601 (2016).

13. Briscoe, J. \& Qamar, U. Pakistan's Water Economy Running Dry (Oxford University Press, Karachi, 2007) (Commissioned by World Bank).

14. Slater, J. India wants to use water as a weapon against Pakistan. A 59-year-old treaty stands in the way. The Washington Post (2019). https://www. washingtonpost.com/world/2019/02/22/indias-threats-pakistan-offer-hint-futurewater-wars/?noredirect=on\&utm_term=.efbaa96c5d95. Accessed 4 Mar. 2019.

15. Gettleman, J. India Threatens a New Weapon Against Pakistan: Water. The New York Times (2019). https://www.nytimes.com/2019/02/21/world/asia/indiapakistan-water-kashmir.html. Accessed 6 Mar. 2019.

16. Hart, G., Rudman, W. et al. U.S. Commission on National Security in the $21 \mathrm{st}$ Century [Hart-Rudman Commission], Supporting Research and Analysis, The Phase I Report on the Emerging Global Security Environment for the First Quarter of the 21st Century, New World Coming: America Security in the 21st Century (15 September 1999), 16; The White House, A National Security Strategy for a New Century (December 1999), 13.

17. Wilner, A. Freshwater scarcity and hydropolitical conflict: between the science of freshwater and the politics of conflict. J. Military Strategic Stud. 8, 11-19 (2005).

18. Kraska, J. Sharing water, preventing war-hydrodiplomacy in South Asia. Dipl. Statecraft 20, 515-530 (2009).

19. Tarlock, A. D. The International Joint Commission and Great Lakes Diversions: indirectly extending the reach of the boundary waters treaty. Wayne L. Rev. 54, 1661 (2008).

20. Nax, N.A. Looking to the Future: The Indus Water Treaty and Climate Change, Conflict and Dispute Resolution Program (Graduate School of University of Oregan, Oregan, 2016).

21. Gleick, P. H. How much water is there and whose is it? In: The World's Water 2000-2001: The Biennial Report on Freshwater Resources (Island Press, Washington, DC, 2000).

22. Shamir, U. Water agreements between Israel and its neighbors. In: Transformations of Middle Eastern Natural Environments: Legacies and Lessons (eds Albert, J., Bernhardson, M. \& Kenna, R.) Bulletin Series, Number 103, 274-296 (Yale School of Forestry and Environmental Studies, 1998).
23. Garretson, A. The Nile river system. In: Proc. American Society of International Law at Its Annual Meeting, Vol. 54, 136-144 (1960). https://doi.org/10.1017/ S0272503700038672.

24. Gerlak, A. \& Schmeier, S. in Oxford Handbook on Water Politics and Policy (eds. Conca, K. \& Weinthal, E.) (Oxford University Press, Oxford, 2016)

25. The World Bank. Indus Water Treaty. World Affairs, 123, 99-101 (1960). http:// www.jstor.org/stable/20669916

26. Boundary Treaty between Canada and the United States. Am. J. Int. Law 19(4), 122-128 (1925). https://doi.org/10.2307/2213187. (Supplement: Official Documents).

27. Elmusa, S. The Jordan-Israel water agreement: a model or an exception? J. Palest. Stud. 24, 63-73 (1995).

28. Abdalla, I. H. The 1959 Nile Waters Agreement in Sudanese-Egyptian relations. Middle Eastern Studies. 7, 329-341 (1971).

29. Morris, M. \& De Loë, R. Cooperative and adaptive transboundary water governance in Canada's Mackenzie River Basin: status and prospects. Ecol. Soc. 21(1), 26 (2016).

30. Barchiesi, S., Welling, R., Dalton, J. \& Smith, M. in Transboundary Water Governance: Adaptation to Climate Change (eds Sanchez, J. C. \& Roberts, J.) (International Union for Conservation of Nature \& IUCN Environmental Law Centre, Gland, Switzerland, 2014).

31. Gleick et al. The World's Water. Volume 7: The Biennial Report on Freshwater Resources (Island Press, Washigton, DC, 2011).

32. Hamner, J. \& Wolf, A. patterns in international water resource treaties: the transboundary freshwater dispute database. Colorado J. Int. Env. Law Policy (1998).

33. UNEP/OSU (United Nations Environment Programme and Oregon State University). Atlas of International Freshwater Agreements (UNEP Press, Nairobi, Kenya, 2002).

34. Fischhendler, I. Legal and institutional adaptation to climate uncertainty: a study of international rivers. Water Policy 6, 281-302 (2004).

35. Klare, M., Smith, M. \& Turton, A. The big question: will global conflict flow from the quest for water security? World Policy J. 26, 5-8 (2009).

36. Mitchell, S. M. \& Zawahri, N. A. The effectiveness of treaty design in addressing water disputes. J. Peace Res. 52, 187-200 (2015).

37. Bagla, P. Along the Indus River, saber rattling over water security. Science $\mathbf{3 2 8}$, 1226-1227 (2010).

38. World Bank. Mediation essentials (English). Mediation series (World Bank Group, Washington, DC, 2017). http://documents.worldbank.org/curated/en/ 153761503566770915/Mediation-essentials.

39. Schmeier, S. The institutional design of river basin organizations-empirical findings from around the world. Int. J. River Basin Manag. 13, 51-72 (2014).

40. UNECE. Convention on the Protection and Use of Transboundary Watercourses and International Lakes. UN Doc E/ECE/1267, New York, 17 March 1992.

41. Akhtar, S. Emerging challenges to indus water treaty: issues of compliance and trans boundary impacts of Indian hydro projects on the western rivers. J. Ins. Reg. Stud. 28, 311-316 (2010).

42. "Pakistan accuses India of "stealing" water." Telegraph, 26 March 2009. http:// www.telegraph.co.uk/news/worldnews/asia/pakistan/5052150/Pakistan-accusesIndia-ofstealing-water.html.

43. Uitto, J. I. \& Duda, A. M. Management of transboundary water resources: lessons from international cooperation for conflict prevention. Geogr. J. 168, 365-378 (2003).

44. Afed, U. K., Jiang, J., Wang, P. \& Zheng, Y. Influence of watershed topographic and socio-economic attributes on the climate sensitivity of global river water quality. Environ. Res. Lett. 12, 104012 (2017).

45. Parkes, L. The politics of 'water scarcity' in the Nile basin: The case of Egypt. J. Politics Int. Stud. 9, 433-480 (2013).

46. Cascão, A. E. Changing power relations in the Nile river basin: unilateralism vs. cooperation. Water Alternatives 2, 245-268 (2009).

47. Climate talks are not enough. Nature 556, 407-408. https://doi.org/10.1038/ d41586-018-04925-4 (2018).

48. Thu, H. N. \& Wehn, U. Data sharing in international transboundary contexts: the Vietnamese perspective on data sharing in the Lower Mekong Basin. J. Hydrol. 536, 351-364. https://doi.org/10.1016/j.jhydrol.2016.02.035 (2016).

49. Lee, T. M., Markowitz, E. M., Howe, P. D., Ko, C.-Y. \& Leiserowitz, A. A 2015 predictors of public climate change awareness and risk perception around the world. Nat. Clim. Change 5, 1014-20 (2015).

50. AQUASTAT (UN Food and Agriculture Organisation Information System on Water and Agriculture). Indus Basin Water Report 37 (2011). http://www.fao.org/nr/ water/aquastat/basins/indus/index.stm.

51. Webersik, C. Climate Change and Security: A Gathering Storm of Global Challenges 44 (Praeger, Santa Barbara, CA, USA, 2010).

52. Adeel, Z., \& Wirsing, R. G. (eds). Imagining Industan: Overcoming Water Insecurity in the Indus Basin (Dordrecht, 2017).

53. FAO. Irrigation in Southern and Eastern Asia in Figures: AQUASTAT Survey 2011. 129-140. (Food and Agriculture Organisation, Rome, Italy, 2012). 
54. Laghari, A. N., Vanham, D. \& Rauch, W. The Indus basin in the framework of current and future water resources management. J. Hydrol. Earth Sysems Sci. 16, 1063-1083 (2012).

55. Eigenbrod, F. et al. The impact of projected increases in urbanization on ecosystem services. Proc. Biol. Sci. 278, 3201-3208 (2011).

56. Immerzeel, W. W., van Beek, L. P. H. \& Bierkens, M. F. P. Climate change will affect the Asian water towers. Science 328, 1382-1385 (2010).

57. Robins, T. E. Defusing hydroelectric Brinkmanship: The Indus Waters Treaty's alternate dispute resolution provisions and their role in the tenuous peace between India and Pakistan. Yearbook Arbitration Mediation 5, 389-408 (2013).

58. Fazil, M.D. Why India must refrain from a water war with Pakistan: threatening Pakistan's water supply will have a negative impact on India and all of South Asia. The Diplomat (2017). https://thediplomat.com/2017/03/why-india-must-refrainfrom-a-water-war-with-pakistan/.

59. Timmerman, J. G., Matthews, J., Koeppel, S., Valensuela, D. \& Vlaanderen, N. Improving governance in transboundary cooperation in water and climate change adaptation. Water policy 19, 1014-1029 (2017). http://wp.iwaponline. com/content/early/2017/07/17/wp.2017.156.

60. Karger, D. N. et al. Climatologies at high resolution for the earth's land surface areas. Scientific Data 4, 170122 (2017). https://doi.org/10.1038/sdata.2017.122.

61. Boucher, O., Bellassen, V., Benveniste, H., Ciais, P., Criqui, P., Guivarch, C., Le Treut, H., Mathy, S. \& Séférian, R. Opinion: in the wake of Paris Agreement, scientists must embrace new directions for climate change research. Proc. Natl. Acad. Sci. USA 113, 7287-7290 (2016).

62. Stewart, I. T., Cayan, D. \& Dettinger, M. Changes in snowmelt runoff timing in western North America on a "business as usual" climate change scenario. Clim. Change 62, 217-232 (2004).

63. Stewart, I. T., Cayan, D. \& Dettinger, M. Changes toward earlier streamflow timing across western North America. J. Clim. 18, 1136-1155 (2005).

64. Arrigoni, A. S., Greenwood, M. C. \& Moore, J. N. Relative impact of anthropogenic modifications versus climate change on the natural flow regimes of rivers in the Northern Rocky Mountains, United States. Water Resour. Res. 46, W12542 (2010).

65. Global Water Partnership. The 2010 GWP Consulting Partners (CP) Meeting with the theme: Exploring the Role of Water Security in Regional Economic Development. Presentation by Technical Committee Chair, Mohamed Ait Kadi, at the CP meeting held in Stockholm, Sweden, 3-4 (2010).

66. Boussalis, C. \& Coan, T. G. Text-mining the signals of climate change doubt. Glob. Environ. Change 36, 89-100 (2016).

67. Dasgupta, N. \& Miglani, S. Troubled waters? India fast-tracks hydro projects in disputed Kashmir. Reuters (16 Mar. 2017). https://in.reuters.com/article/ indiapakistan-water/troubled-waters-india-fast-tracks-hydro-projects-indisputed-kashmir-idINKBN16N0XE.

68. Babel, M. S. \& Wahid, M. Freshwater Under Threat South Asia: Vulnerability Assessment of Freshwater Resources to Environmental Change. (United Nations Environment Programme (UNEP), Nairobi, 2008).

69. Laghari, A. N., Vanham, D. \& Rauch, W. The Indus basin in the framework of current and future water resources management. Hydrol. Earth Syst. Sci. 16, 1063-1083 (2012). https://doi.org/10.5194/hess-16-1063-2012.
70. Certain Expenses of the United Nations. Advisory Opinion. I.C.J. Rep. 151 (1962).

71. Walsh, B. et al. Pathways for balancing $\mathrm{CO} 2$ emissions and sinks. Nat. Commun. 8 14856 (2017)

\section{ACKNOWLEDGEMENTS}

We thank Hector Malano for the comments and suggestions provided. This study was funded by the Higher Education Commission of Pakistan under the grant number (TDF-02-103).

\section{AUTHOR CONTRIBUTIONS}

M.U.Q. led the project and recommended policy points. P.C. assisted in finding the relevant literature. M.U.Q. and M.A. reviewed the literature. M.U.Q. and P.C. wrote the manuscript.

\section{COMPETING INTERESTS}

The authors declare no competing interests.

\section{ADDITIONAL INFORMATION}

Correspondence and requests for materials should be addressed to M.U.Q.

Reprints and permission information is available at http://www.nature.com/ reprints

Publisher's note Springer Nature remains neutral with regard to jurisdictional claims in published maps and institutional affiliations.

Open Access This article is licensed under a Creative Common Attribution 4.0 International License, which permits use, sharing, adaptation, distribution and reproduction in any medium or format, as long as you give appropriate credit to the original author(s) and the source, provide a link to the Creative Commons license, and indicate if changes were made. The images or other third party material in this article are included in the article's Creative Commons license, unless indicated otherwise in a credit line to the material. If material is not included in the article's Creative Commons license and your intended use is not permitted by statutory regulation or exceeds the permitted use, you will need to obtain permission directly from the copyright holder. To view a copy of this license, visit http://creativecommons. org/licenses/by/4.0/.

(c) The Author(s) 2019 